\title{
EFL Students' Social Identities Construction Through Gender-Based Short Stories
}

\section{Construcción de Identidades Sociales en Estudiantes de Lengua Extranjera a través de Historias Cortas Basadas en Temas de Género}

Catherine Benavides Buitrago'

Citation/ Para citar este Artículo: Benavides, C. (2017). EFL Students' Social Identities Construction Through Gender-Based Short Stories. Colomb. Appl. Linguist. J., 19(1), pp. 11-21.

Received: 01-Jul-2016 / Accepted: 08-Nov-2016

DOI: http://dx.doi.org/10.14483/calj.v19n1.10641

\begin{abstract}
This article reports an action research study that took place in a public school in Bogota with 38 students from $7^{\text {th }}$ grade who were between 12 and 16 years of age. The study intended a) to identify discourses students draw on to construct social identities in the EFL classroom while reading short stories about gender topics b) to describe social identities constructed discursively in relation to gender-based short stories and c) to study the potential relationship between these discursively constructed social identities in gendered-related reading activities and foreign language learning. This post-structuralist study focused on the topics of gender, social identities, and students' discourses, definitions that were defined and described in its theoretical framework. Data were collected by observing and analyzing three pedagogical units based on short stories about equality, multiplicity, and respect and designed by following the stages of the Task Based Learning Approach (TBL). Field notes, video and audio recordings, and students' artifacts were analyzed by following the steps proposed by grounded theory (GT; Charmaz, 2006) and the principles of critical classroom discourse analysis (CCDA; Kumaravadivelu, 1999). Data analysis revealed a main category and three subcategories which showed the relationship between the gender-based short stories read by the students and the discourses they created during the lessons.
\end{abstract}

Keywords: EFL classroom, gender, short stories, social identities, students' discourses

\section{Resumen}

El presente artículo se basa en una investigación-acción de carácter cualitativo realizada en un colegio público de Bogotá con 38 estudiantes de grado séptimo con edades comprendidas entre 12 y 16 años. Éste estudio tiene como objetivos principales: a) identificar los discursos que los estudiantes crean para construir identidades sociales en el salón de clases mientras leen historias cortas basadas en temas de género b) describir identidades sociales construidas discursivamente en relación a historias cortas basadas en temas de género y c) estudiar la relación potencial entre éstas identidades sociales construidas discursivamente a través de las lecturas basadas en temas de género y el aprendizaje de la lengua extranjera. Éste estudio post-estructuralista se enfocó en los temas de género, identidades sociales y discursos de estudiantes, definiciones que fueron definidas y descritas en el marco teórico. Los

1 Universidad Distrital Francisco José de Caldas, Bogotá, Colombia. ktrock84@yahoo.com 
datos fueron recolectados por medio de la observación y el análisis de tres unidades pedagógicas (basadas en historias cortas sobre temas de igualdad, multiplicidad y respeto) las cuales fueron diseñadas siguiendo las etapas del Task Based Learning Approach (TBL). Los diarios de campo, videos, audios y los trabajos de los estudiantes fueron analizados siguiendo los pasos propuestos por el grounded theory (GT) (Charmaz, 2006), y los principios de Critical Classroom Discourse Analysis (CCDA) (Kumaravadivelu, 1999). El análisis de los datos reveló una gran categoría compuesta por tres sub-categorías que mostraron la relación existente entre las historias cortas basadas en tema de género que los estudiantes leyeron y los discursos que ellos construyeron durante las sesiones de clase.

Palabras clave: identidades sociales, historias cortas, género, discursos de los estudiantes, clase de lengua extranjera

\section{Introduction}

Nowadays, Colombian teachers have to face different concerns at schools that have never been considered in the past. Due to the fact that we are living in a post-conflict era, teachers' practices should be changed as they should include activities in which students can understand, analyze, and reflect upon the reality that surrounds them. Moreover, the recent peace agreements in the country also give people the opportunity to start thinking about the possible ways in which sociocultural values can be reborn in our society. Classrooms should become a place in which respect can be the main aspect that supports the learning process, as it is the scenario where interaction takes place. Interaction then becomes the means through which students share their viewpoints, agreements, or disagreements about certain topics at the same time that they learn how to respect each other's opinions. Furthermore, including gender topics in the educational curriculum is considered important as they are related to promoting social values which is one of the biggest aspects that Colombian society has to foster today. Everyday news show that people and especially current students, should start thinking about respecting and accepting diversity in order to build a better future based on respecting such multiplicity.
Through this article different results obtained from a research study conducted in a public school in Bogota, Colombia will be shown. The institution and the participants of the study were chosen by convenience, as it was the place and the group of students that were assigned to me during the period of time when the research took place. The participants were 38 students from $7^{\text {th }}$ grade who were between 12 and 16 years of age. The main objectives of the study were a) to identify discourses students draw on to construct social identities in the EFL classroom while reading short stories about gender topics, b) to describe social identities constructed discursively in relation to gender-based short stories, and c) to study the potential relationship between these discursively constructed social identities in gendered-related reading activities and foreign language learning. As such, the present study seeks to answer the following research question: What social identities are discursively constructed by EFL learners when facing gendered short stories?

At the beginning of the process, a survey was given to students $(n=38)$ and English teachers $(n=6)$ from the institution in order to identify their viewpoints about the main needs that should be considered in the EFL classroom. With this survey, it was shown that students wanted to focus on the development of the speaking (38\% of students) and reading (32\% of students) skills as well as on the reading of love (17\%), adventure (13\%), and horror (13\%) stories. Teachers (90\%) also considered that reading and speaking were the most important skills a language teacher should focus on, as it is through these abilities that students succeed the language. The other $10 \%$ of the teachers thought that writing was the main skill to be developed in students.

Considering Sanchez's (2000) point of view about including "historical, cultural and social environment when developing literacy in the classroom" (p. 58), it was important to incorporate real life language, and it seemed that the best way to do so was by reading short stories that were close to and based on students' real context. Besides, as Sanchez (2000) also suggested school should be opened to reality and students could be practicing the language at the same time that they were talking, writing, or reflecting on their own context. 
Class observations were then conducted in order to find out a possible topic that could be introduced into the classroom to create opportunities for students to discuss as a way to see what would emerge while they interacted and participated in the lesson as part of the "usual" practices in the classroom. After two observation classes, where I paid special attention to participants' discourse interactions, the topic of gender came up as the majority of the students reproduced some patterns related to gender that have been socially constructed and present in their discourses when interacting in class. For instance, students were given a piece of cardboard with two human silhouettes in order to let students put the corresponding clothes according to the pieces of fabric they brought to class. While looking at the kinds of clothes they put on the silhouettes, I could see that the majority of the students gave a specific gender to their silhouettes based on the color and kind of fabrics they had. In other words, they gendered the silhouettes depending on the clothes they could put on each one of them.

This situation led me to analyze that there are few studies in Colombia related to gender topics and that it is a very important aspect to take into account when students' ideologies can interfere in their classmates' access to language learning. To illustrate, students saw an example from a story where the main character was a male housekeeper but a student (male) argued that cleaning was only for women. The problem emerged when some students limited his participation to the interaction when they realized that he had other ideas, different from theirs, in terms of gender topics. His access to language learning was limited when his classmates started criticizing his answer for being chauvinist and as a result he stopped participating in the lesson. His learning process was limited and denied by his own classmates.

Through the information collected from the observations, the surveys and the students' context, I considered it was necessary to make some changes in the methodology of my English classes as they had been focused on grammar-based activities. The traditional grammar explanation and the activities and texts based on hypothetical situations were presented to students before this change was made. I considered that students needed more opportunities to express their points of view during the lessons; to do that, they needed to acquire more English vocabulary, and one way to do it was by reading short texts. I also realized that short stories could be the best means through which students could learn about many important topics addressed in the stories, become proficient users of the target language, and at the same time they could become more aware of different ideas, ways of thinking and acting.

\section{Theoretical Framework}

\section{Gender}

Through history, we have had clear examples of distinctive ways in which people behave, treat, and communicate with each other depending on biological and cultural differences. Such distinctions are evident today in our classrooms, especially in the EFL context where the aspects of gender, identity, and culture play an important role when learning, communicating, and interacting in a foreign language. Gender has been considered lately as an important part of the language learning process as its influence may change classroom interaction and the access to the learning of the target language.

Norton and Pavlenko (2004) stated that "we see gender not as a dichotomy or an individual property but as a complex system of social relations and discursive practices differentially constructed in local contexts" (p. 3). The existent relationship between males or females cannot be linked to the biological aspect only; it also has to do with the social, cultural, economic, and political aspects as they are socially constructed.

According to Connell (2002), the aspect of gender is "a matter of the social relations within which individuals and groups act" (p. 9). Gender has been defined by certain groups within the various cultures as these groups state some specific models people are supposed to follow. This is one of the aspects to be studied and discussed in our classrooms in order to help students understand and respect gender differences. Social relations should place everyone at the same level without any difference of gender or as everyone is simply treated as humans without 
bearing in mind gender differences as well as likes, dislikes, culture, religion etc. In other words, it is important to mention that the same should happen in our classrooms, as gender is a matter that concerns everyone in terms of recognizing and respecting each other's ways of life or thinking and what we see today is that not all students or even teachers are able to respect those differences. Some students or teachers just discriminate against gays or women, for instance, just because they think of them as "weaker" people or because they do not follow the established dichotomy of male or female. When teaching a lesson, in this case in English class, teachers should try to develop different activities related to the topic of gender, not just to make students debate about it by using the target language, but also to show them that we should not discriminate against others for being or thinking differently.

Nielsen and Davies (2008) state that "to do gender in the classroom is to continuously negotiate, maintain, or oppose these positionings offered in classroom talk" (p. 160). While interaction takes place in or outside the classroom, students also reveal their positions on a certain topic and that is why students' discourses also became an essential aspect to include and consider in future lesson planning.

\section{Students' Discourses}

According to Sunderland (2000), "interaction has to do with the way in which some teachers spend more or less time giving students the corresponding opportunities to learn" (p. 161). Those opportunities are given to students through different activities in order for them to improve their learning process, but sometimes there are students that feel afraid of mispronouncing or even using the wrong expression or word. As a result, they never interact, they just project their discourses by showing their decision of not participating in the lessons and, instead, they project them through written activities they know will never be presented in public. On the contrary, there are some others that do not feel afraid of interacting because it becomes the way in which they demonstrate higher performance in the target language. When students interact or express themselves, they also show their feelings or viewpoints, in other words, their inherent discourses (even the students that do not interact much are projecting their own discourses). This means that they are learning not only the target language but also about others' viewpoints.

Tannen (1996) states some cautions to keep in mind whenever language is observed in interaction and suggests that "one must take into account a) the context in which a linguistic strategy is used, b) the conversational styles of the participants, and c) the interaction of those styles" (p. 342). The way participants interact, take the floor, or even interrupt each other show their discourses, which sometimes work as a means to empower or support others giving them the chance to participate and feel free to interact. Likewise, students who do not participate in the lessons also state their position about the topics discussed in class whether they do not care about the topic or because they state their counterdiscourse by staying quiet.

Litosseliti (2006) defines discourse as "the language used in a group of people that acquires multiple meanings in context in relation to each member's ideologies or ways of seeing the world" (p. 47). Through students' discourses, we can identify their ideologies as the language they use in and outside the classroom can give proof of that. Such language shows students' ways of thinking and even sometimes the desire of some of them to excel among others. It can be seen when we pay special attention to students' interactions as dominant discourses appear while they talk.

As teachers, we have the opportunity to analyze students' discourses to identify their positions of power and powerlessness (Litosseliti, 2006). Some of them can be categorized as gendered discourses in the sense that according to their behavior they can be representing their own identity. When discussing the gender-based short stories, students expressed their ideologies through their own discourses and can also show their power position in the classroom. Students conversational styles and the interaction of those styles (Tannen, 1996) show the participants' position in the classroom while developing the skills they tend to interrupt each other to empower themselves or to support others' ideas. 
As discourses involve people's identities, it becomes vital to talk about those social identities that emerge while individuals communicate and express themselves with each other.

\section{Social Identities}

Identity includes two concepts according to Gentry and Campbell (2002):

First is self-concept: the set of beliefs one has about oneself. This includes beliefs about one's attributes (e.g., tall, intelligent), roles and goals (e.g., occupation one wants to have when grown), and interests, values, and beliefs (e.g., religious, political). Second is self-esteem, which involves evaluating how one feels about one's self-concept. (p. 15)

It is important to develop activities in the classroom that allow students to unveil their identities and discuss certain topics with others. Although it is a difficult process when working with adolescent students, it becomes imperative to offer students the opportunity of reading short stories about gender topics in order to give them the chance to discuss the stories and at the same time show and build new identities in the classroom. In addition, while stating their points of view, students could use the target language to negotiate and build new meanings with their classmates.

Additionally, as teenagers build their identities, they have to deal with peer pressure from their social group. Learning a foreign language can be a pleasant experience, but it can also threaten one's identity. Teenagers may feel awkward when speaking English which, at the same time, could make them feel different from their peers resulting in an unpleasant experience. In addition to the pressure of not giving an answer in English or of making grammar or pronunciation mistakes, students felt the pressure of having a different point of view as evidenced with the student that gave his opinion by saying "cleaning is only for women." The solution, according to Deubelbeiss (2010) is to create "a very warm, inviting, and risk taking atmosphere in the classroom" and to reflect on whether the lessons "help or hinder peer-bonding" (para. 1). That is why it is really important for students to feel comfortable when building their own identity bearing in mind the help and support from others as school becomes their community of practice where judgments and mockery should never take place.

Tajfel and Turner (1979) claim that social identities emerge within and outside particular groups and they are defined in terms of their members or the members of other groups. Likewise, Deaux (2001) claims that "the term 'social identity' refers specifically to those aspects of a person that are defined in terms of his or her group memberships" (p. 1059). As these authors assert, being part of a group is taking into account not only how we define ourselves but also how others define us as members, or not, of a specific group. Our behavior, feelings, likes, dislikes, etc., can also place us as members of a group. The idea of differentiating the groups works as a way to achieve superiority among other groups. The same happens in classrooms as students belong to different groups and are defined by others as members of those groups because they share specific patterns. There are groups that tend to dominate the dynamics of the classroom by following positive or negative practices of behavior, for instance.

Another important aspect to consider within social groups is leadership. Hogg and Tindale (2005) define it as "the ability to transform individual action into group action by influencing others to embrace as their own, and exert effort on behalf of and in pursuit of, new values, attitudes, goals, and behaviors" (p. 151). Groups always have followers and leaders who are identified with the social identity defined by their members and by members of other groups. These leaders belong to a higher status within their groups because they have gained a particular confidence to make beneficial decisions for the group. In other words, they follow the stereotype of a leader. When developing the activities specific leaders were identified during the lessons as some students were taking the floor in more opportunities than others. The majority of their classmates followed and agreed with their ideas even more when they were promoting values, defending human rights, or stating unfair real life cases. 


\section{Methodology}

This was a qualitative action research study that followed some of the critical classroom discourse analysis (CCDA) principles proposed by Kumaravadivelu (1999). These principles were taken into consideration while analyzing the collected data. Such principles refer to the way in which participant discourses arise and are socially constructed not only by what students experience in the classroom (minisociety) but also by the social context in which they grow up. They include the importance of analyzing the dominant and dominated discourses in the classroom as well as the resistant discourses and how they affect teaching and learning. The principles mention that the teacher has to promote critical engagement bearing in mind the sociocultural influence on students' identities, beliefs, voices, fears, and anxieties while negotiating meaning. Furthermore, they state that teachers should theorize what they practice and practice what they theorize at the same time they develop the skills to observe and analyze the discourses that appear in the classroom while students interact (Kumaravadivelu, 1999).

As CCDA does not have an explicitly defined stage-by-stage process, some components from grounded theory (GT) proposed by Charmaz (2006) were taken into consideration as well. According to Charmaz (2006), "we [grounded theorists] construct data through our observations, interactions, and materials that we gather about the topic or setting" (p. 3). In this case some field notes based on the observation of the lessons, audio recordings from students' interactions and some participants' artifacts (power point presentations, drawings, and short written compositions) were constructed as data. Then, some of the aspects proposed by GT were studied to analyze such data. These included using comparative method, constructing analytical codes and categories, simultaneous involvement in data collection and analysis, and conducting the literature review after developing an independent analysis in order to see the relations between what was found in data and what is stated by theorists.

\section{Analysis and Discussion of Results}

It is essential to mention at this point that for ethical issues a consent form was signed by students' parents to give the corresponding permission to use their oral interventions (video and audio recordings) and their work (ppt presentations, drawings and interviews). Besides, as participants were underage their names were changed in order to protect their identities; instead, some pseudonyms proposed by the students were used for data analysis, the steps defined by Corbin and Strauss (1990) for GT were followed and Atlas.ti software was used to facilitate such process. The first step was open coding in which different codes emerged from the data. Open coding allowed the comparison among events, actions, and interactions. Some of the codes were joined while examining their similarities. The second step was axial coding which permitted me to group different codes into categories that reflected their commonalities (Corbin \& Strauss, 1990). A single main category was created during the data analysis and three subcategories emerged from it as seen in Figure 1.

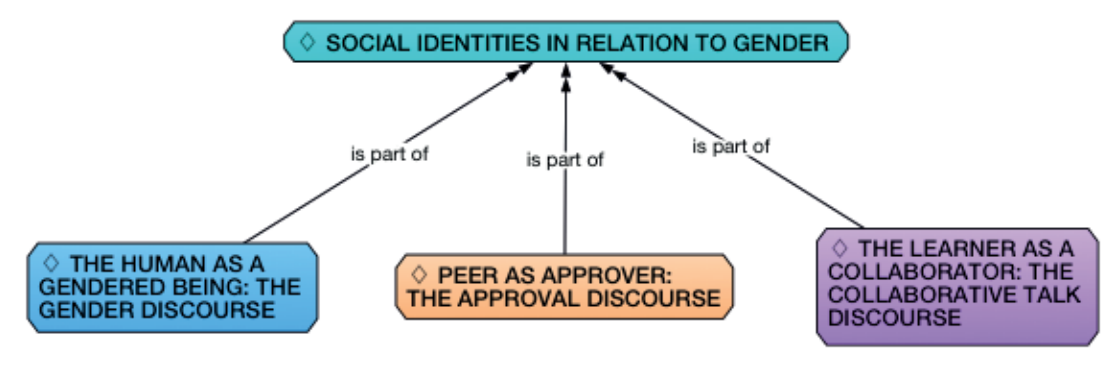

Figure 1. Category 1. Social identities in relation to gender (Atlas.ti display). 
The main category was named "social identities in relation to gender" because the various social identities that were constructed during the process of data collection were related to gender topics. It is essential to mention that the different genderbased short stories participants read worked as an excuse to unveil their social identities in the classroom through the conversations and debates they built during their interactions while discussing such gender topics. This main category was divided into three different sub-categories that were named taking into account Baxter's (2003) discourses in the classroom. Those identities were defined in a similar manner considering the different created codes and the way in which they could be grouped together.
The human as a gendered being: The gender discourse. The first subcategory was defined by Baxter (2003) as "gender differentiation" taking into consideration the distinctions between sex or gender. In this case, the name was changed as collected data did not only show gender differentiation but also, in some cases, how students could internalize the fact that human beings possess masculinities and femininities without making the distinction between male or female inner elements. In other words, some of the students could break up the gender differentiation as the started to combine male and female aspects in a single person. They saw the human as a gendered being who is different from everyone else and that should be respected and/or accepted by others.

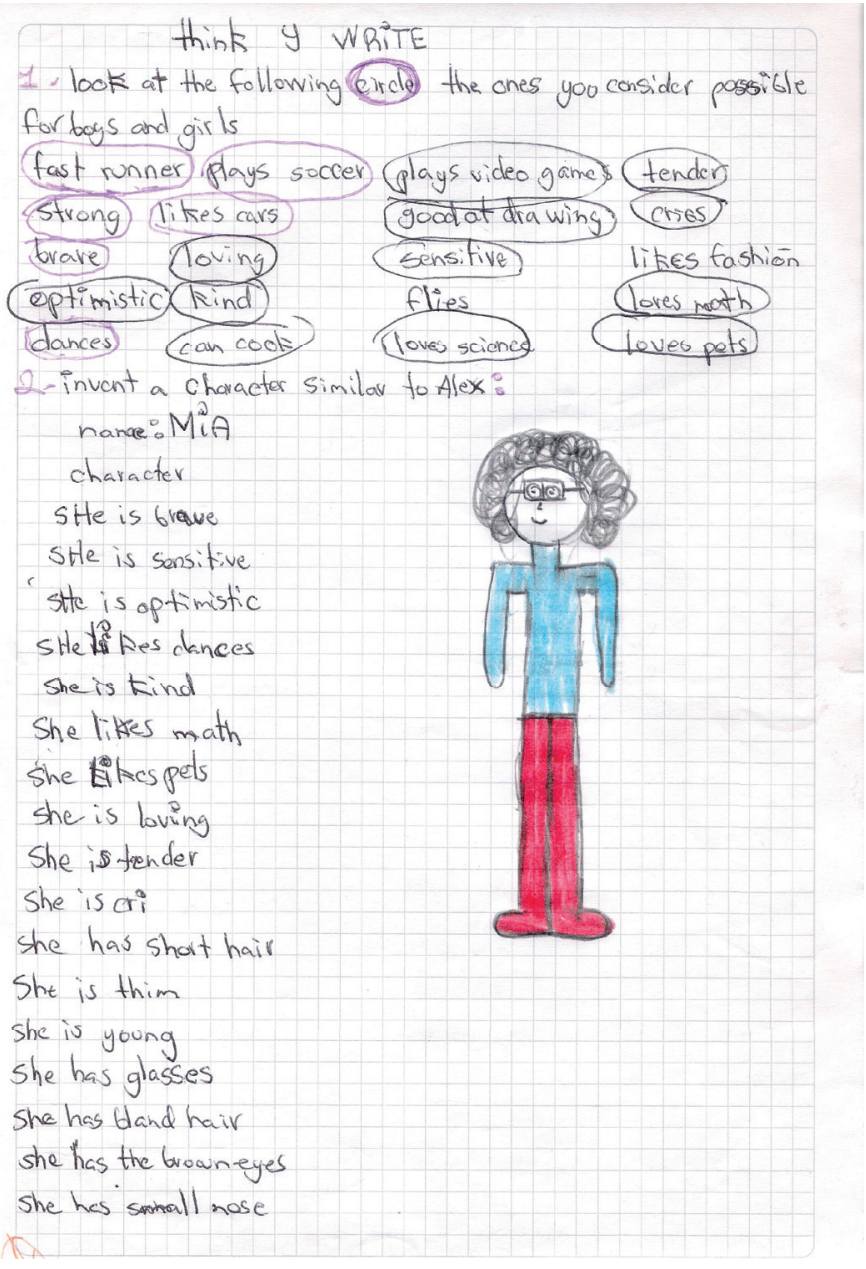

Figure 2. Artifact (ART-SH-1.3) 
The fact that some students showed a single person with feminine and masculine aspects seem to be crucial when talking about their social identities. They demonstrated that their identities are not necessarily stuck to the social constructed gender stereotypes of male and female.

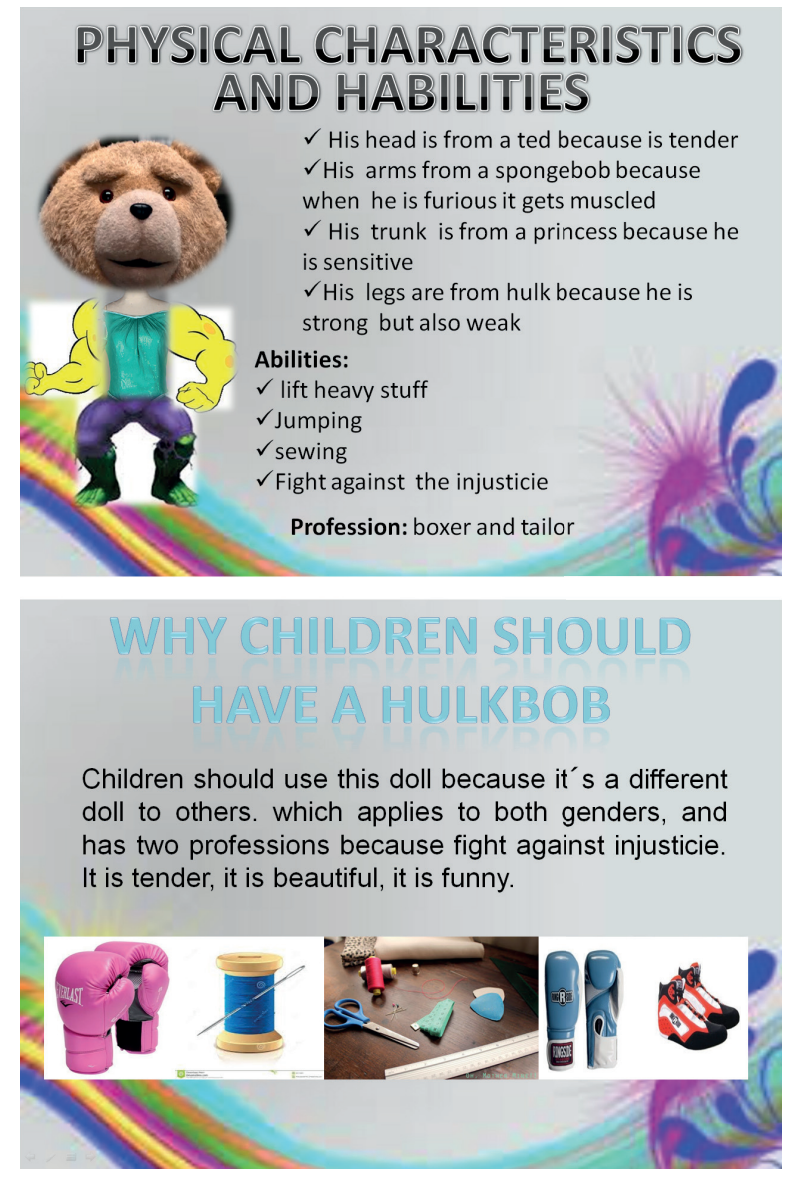

Figure 3. Artifact (ART-PPT-3.2)

The first example (Figure 2) has two different parts; the first one (above) shows that this student considered the aspects circled as possible for boys and for girls. Eighteen out of twenty are marked with a circle, which reflects the student discourse about sharing feminine and masculine aspects for a single person no matter the sex to which they belong. The second part (below) shows the character she created and the different aspects she used to describe it. The character's name is Mía, a girl with a male physiognomy that contains feminine aspects as being sensitive, loving, and tender.

In the second example (Figure 3), students had to create a toy which included some feminine and masculine characteristics with the excuse of creating something that could be used by boys and girls at the same time. The group that created "Hulkbot" in the example included male and female parts, professions, and characteristics (strength, sensitiveness, tenderness, boxer, and tailor). They also included that the toy was different from others as it was not for members of a specific sex. These activities showed how students included both aspects in a single character, including themselves, to show that everyone can have both aspects. This showed that students were following some of the ideas presented in the short story that they read about a toy which included masculine and feminine parts, shown as abilities, without caring about its appearance.

Peer as approver: The approval discourse. The second subcategory's was based on Baxter's (2003) proposal called "peer approval" which is defined as "the ways in which social relations in the classroom are governed by the support and approbation of its participants" (p. 92). The name of this category was changed in order to consider the corresponding identity this discourse could be joined to. In this case, this approval discourse was expressed as the way in which some participants were demanding over others, judging other's opinions, and disempowering others while developing a certain activity which demonstrates what Francis (1998, as cited in Baxter, 2003, p. 92) called "popularity and even friendship patterns." Some of the students paid special attention to what some of their classmates said, if they approved or disapproved of what they were saying during an intervention. At times this situation did not allow some students to participate in the lessons or even express what they really though about what was being discussed. When students realized that some of their classmates could judge their opinions or make fun of their mistakes, they just decided to stop participating.

Teacher: Ok, ¿será que la carita me ayuda?

Frank: Sí porque ese nombre es de mujer

Andrés: Si ese nombre es de mujer 
David: Cierto profe que puede ser utilizado por cualquiera de los dos? si es mujer o hombre? (TRFN05 01-06-15)

Sofía: o sea, esta y ya

Anahí: ay, bueno sí sí sí, sigamos

Talía: has [gor has]?

Sofía: ush, ¿eso qué significa?

Talía: she's has [blan her]

(TR2 Guess who)

In the first example (Transcript Field Note 05) the teacher asked students to tell her if a character from the "Guess Who" board game was considered by them as a girl or a boy by seeing the name that appeared on the cardboard while they were playing. When they saw that the character had the same name as one of their classmates, (Danny) some of the students started saying that the name is for a girl in order to disempower him in front of the whole class. Although his classmates are trying to disempower him, he looks for the teacher's help to try to disempower them as well.

The other example (Transcript 2 Guess Who) shows that Anahí and Talía were playing Guess Who and sometimes they asked for Sofía's help. She intervenes to help them but at the same time she disempowered Talía when she saw that she was mispronouncing some of the words that she used to ask a question. With the expression "ush, ceso qué significa?" Sofia discredited Talía in front of her game partner even though she tried to correct her own sentence.

The learner as a collaborator: The collaborative talk discourse. The third sub-category comes from the classroom discourse explained by Baxter (2003) as "the collaborative talk discourse." It refers to the "application of apparent sets of expectations from both teachers and students that most assessable talk in the English classroom should be co-operative, facilitative, supportive and involve active listening" (Baxter, 2003, p. 92). The name of this sub-category was modified in order to make the relation to the corresponding identity it refers to, in this case the learner as a collaborator.

David: is, is, is bad, ehhh, ¿cómo se dice por qué?
Students: because

David: ah, [becáus] Lisa is, ¿cómo se dice

burlando?

Students: laugh

David: [láun, láun] laughing is bad because

Lisa laughing of Alex.

(TRFN03 27-05-15)

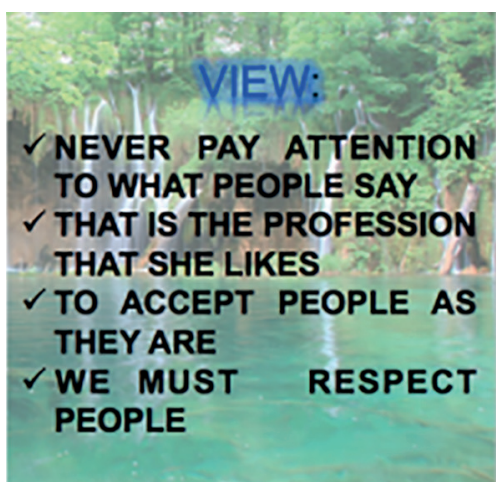

Figure 4. Artifact (ART-PPT-2.5)

The first example (Transcript Field Note 03) showed the way in which a student was asking his classmates for help with some vocabulary to build a complete sentence. This sample showed a student soliciting their classmates for different aspects he saw as necessary to accomplish the assigned task. The slides in Figure 4 show the point of view of the students that presented the case of this mechanic woman who suffered from the discrimination of her male co-workers. These students reflected about accepting people's likes and jobs. Both examples showed that some students could make the corresponding reflection about the different things that happen every day at school or in other places, and also the way they worked collaboratively to help and learn from other's life experiences.

\section{Conclusions}

The social identities that were discoursively constructed in the classroom were focused on gender topics. This happened because of the fact that they read gender-based short stories as an excuse to unveil their social identities while discussing 
and giving opinions. Three different identities were identified from the data analysis. When students read the short stories they realized that gender topics were not included in the lessons of the school. They saw an opportunity to talk about some stories based on the lives of different characters who were similar to them in terms of age, likes, and dislikes. They also compared the events from the stories to real life events that were really close to their familiar and social contexts. This situation led students to the point of discussing social issues and stating their own viewpoints about those topics. In other words, the classroom became a place to construct social discourses by considering each other's ideas.

The first social identity was identified as seeing humans as gendered beings. Some students could identify and break up the gender stereotypes that were present in everyday life. They also showed their disagreement with any act of discrimination and also claimed the right of being different and respecting others' differences. In other words, reflection and criticality took place in the classroom as a way of becoming better human beings.

The second social identity that emerged was related to peer approval in which some students were asking for others' validation while participating in the activities. Some students were trying to excel in the classroom and sometimes they disempowered others by showing their better performance in the language while participating, or they simply corrected one another in a rude way. The important part related to this social identity was to show students a way to respect each other in order to give everyone the opportunity to learn and to have access to knowledge no matter their different viewpoints.

The third social identity arose after identifying repetitive situations in which students tended to collaborate with each other in terms of developing an activity or helping others to use the target language. As social identities are co-constructed, it is essential to mention that collaboration in the classroom was a necessary tool to build discourse. When students collaborated with each other they were portraying themselves and others' identities during the interactions. As they were helping each other with language and group work issues they were also showing their identities as immediate actors in their own learning process.

It is imperative not to forget that students' previous knowledge and beliefs were present during their interventions and that this knowledge could have possibly been modified or negotiated while interacting in the classroom with other classmates. Some students stated a specific discourse at the beginning of the implementation phase and it continued being the same at the end of the process. The most important part was not if their discourses changed or not, but the fact that students were more aware of respecting each other's viewpoints and that they did not try to change others' opinions.

As a plus, participants also practiced different values through the whole process. They affirmed that it is important to respect and accept other people and not to judge them for what can be seen in the outside. Acceptance was also an aspect that students mentioned several times in order to show that people's differences should be accepted as human beings are all diverse.

\section{Pedagogical Implications}

The study contributed to the development of the curriculum from the school in which the implementation took place as the grammar-based content was put aside in order to give space to the reading of short stories with gender topics. Debate and discussion played an important part when students intended to give personal opinions or to show agreement or disagreement with some unfair situations they saw represented in the stories.

The implementation phase gave me the opportunity to create new material for the students as the school where I work does not follow a specific book or workbook. Furthermore, creating material that could be gender based was a very rewarding experience as students stated at the end of the process that they liked it a lot because they could see some current social problems. 
Students were also able to create materials for the lessons through the use of some electronic sources such as PowerPoint presentations and the use of the Edmodo educational platform. This facilitated the process of making corrections before presenting the final product. In addition, this platform was useful for some of the classes in which students used the blended learning approach.

The various activities had a clear effect on students' classroom and social contexts as now they are more aware of the situations that can affect their environment. They became more reflective about the different problems and issues that surround them in terms of gender topics.

\section{References}

Baxter, J. (2003). Developing an FPDA approach: The classroom study. In J. Baxter (Ed.), Positioning gender in discourse: A feminist methodology (pp. 80-100). New York, NY: Palgrave Mcmillan.

Charmaz, K. (2006). An invitation to grounded theory. In K. Charmaz (Ed.), Constructing grounded theory: A practical guide to qualitative analysis (pp. 1-12). California: SAGE Publications Ltd.

Connell, R. (2002). The question of gender. In R. Connell (Ed.), Gender (pp. 2-11). Cambridge, MA: Polity Press.

Corbin, J., \& Strauss, A. (1990). Grounded theory research: Procedures, canons, and evaluative criteria. Qualitative Sociology, 13(1), 3-21.

Deaux, K. (2001). Social identity. In J. Worell (Ed.), Encyclopedia of women and gender: Sex similarities and differences and the impact of society on gender (pp. 1059-1068). Kentucky, USA: Academic Press.

Deubelbeiss, D. (2010). The teenaged language learner. Retrieved November 16, 2014, from EFL 2.0 Teacher
Talk: http://ddeubel.edublogs.org/2010/08/02/theteenaged-language-learner/

Gentry, J., \& Campbell, M. (2002). Developing adolescents: A reference for professionals. Washington, DC: American Psychological Association.

Hogg, M., \& Tindale, S. (2005). Social identity, influence, and communication in small groups. In J. Harwood $\mathcal{E}$ H. Giles (Eds.), Intergroup communication: Multiple perspectives (pp. 141-164). New York: Peter Lang Publishing .

Kumaravadivelu, B. (1999). Critical classroom discourse analysis. TESOL Quarterly, 33(3), 453-484.

Litosseliti, L. (2006). The shift of discourse: The discoursive construction of gendered identities. In L. Litosseliti (Ed.), Gender and language: Theory and practice (pp. 47-70). New York, NY: Hodder Education.

Nielsen, B., E Davies, B. (2008). Discourse and the construction of gendered identities in education. In Encyclopedia of language and education (Vol. 3, pp. 159-169). USA: Kluwer Academic Publishers.

Norton, B., \& Pavlenko, A. (2004). Gender and english language learners: Challenges and possibilities. In J. Burton (Ed.), Gender and English language learners (pp. 1-12). Alexandria, VA: TESOL Inc.

Sanchez, J. (2000). La lingüística aplicada y la enseñanza del inglés como lengua extranjera: Su encuentro en los proyectos pedagogicos. Enunciación, 4(1), 56-61.

Sunderland, J. (2000). New understandings of gender and language classroom research: Texts, teacher talk and student talk. Language Teaching Research, 4(2), 149-173.

Tajfel, H., \& Turner, J. (1979). An integrative theory of intergroup conflict. In W. Austin \& S. Worchel (Eds.), The social psychology of intergroup relations (pp. 33-47). England: Pacific Grove.

Tannen, D. (1996). Gender in research on language: Researching gender-related patterns in classroom discourse. TESOL Quarterly, 30(2), 341-344. 